\title{
THE LIFE OF CHARLES LEDGER
}

\section{(1818-1905)}

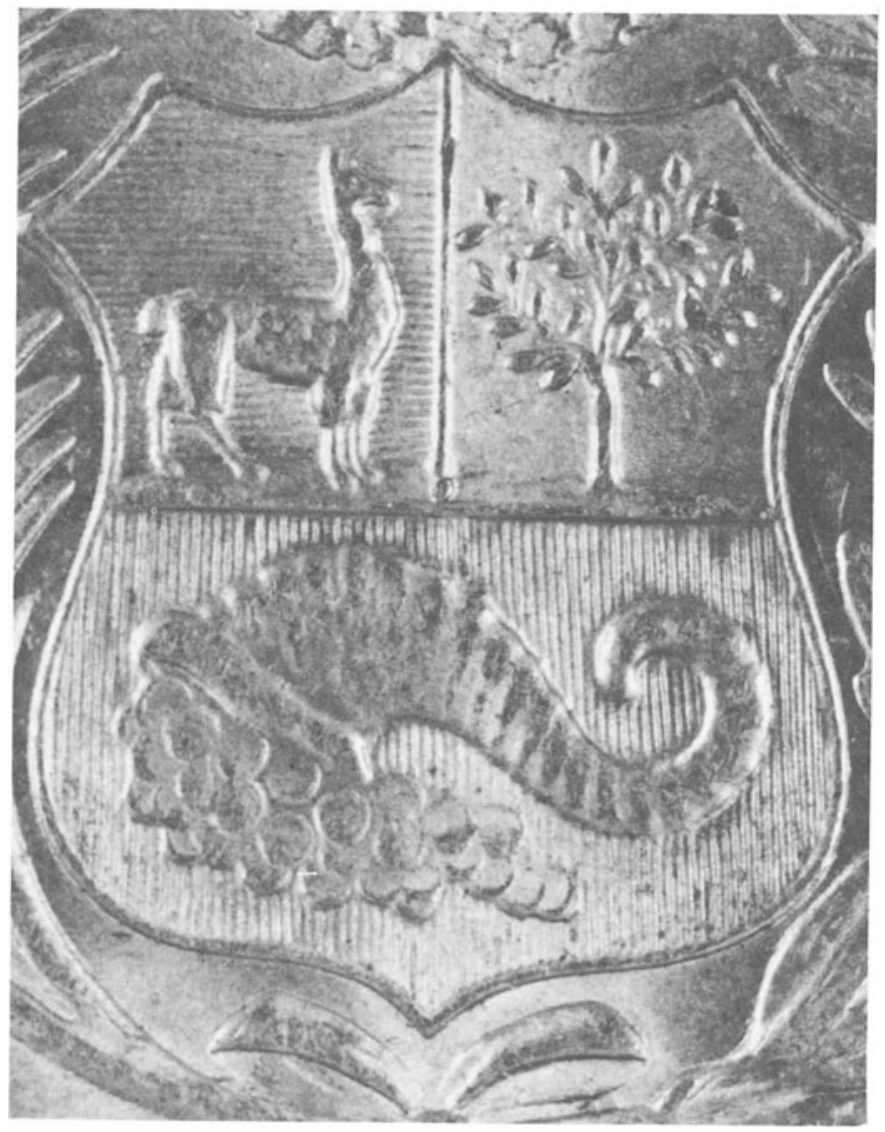

Fig. 1 Coat of arms of Peru, showing alpaca, cinchona and cornucopia 


\section{The Life of Charles Ledger (1818-1905)}

Alpacas and Quinine

Gabriele Gramiccia

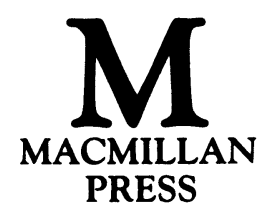


(C) Gabriele Gramiccia 1988

Softcover reprint of the hardcover 1st edition 1988 978-0-333-45710-8

All rights reserved. No reproduction, copy or transmission of this publication may be made without written permission.

No paragraph of this publication may be reproduced, copied or transmitted save with written permission or in accordance with the provisions of the Copyright Act 1956 (as amended), or under the terms of any licence permitting limited copying issued by the Copyright Licensing Agency, 33-4 Alfred Place, London WC1E 7DP.

Any person who does any unauthorised act in relation to this publication may be liable to criminal prosecution and civil claims for damages.

First published in 1988

Additional material to this book can be downloaded from http://extra.springer.com.

Published by

THE MACMILLAN PRESS LTD

Houndmills, Basingstoke, Hampshire RG21 2XS

and London

Companies and representatives

throughout the world

ISBN 978-1-349-09951-1 ISBN 978-1-349-09949-8 (eBook)

DOI 10.1007/978-1-349-09949-8 


\section{Contents}

The Figures viii

The Colour Plates and Map of the Regions of South America ix

Travelled by Ledger

Preface $x$

Acknowledgements xiii

1. The Early Years 1

1.1 Origins 1

1.2 Growing up in London (1818-1836) 2

1.3 First experiences in Peru from Lima to Tacna (1836-1844) 5

$\begin{array}{lll}1.4 & \text { Commotion and gossip (1844) } & 14\end{array}$

1.5 First expeditions in search of cinchona (1844-1847) 16

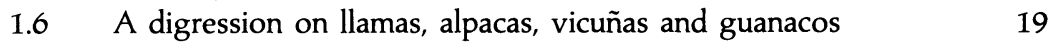

2. The Alpaca Enterprise, not Forgetting Cinchonas 23

2.1 At Chulluncayani, preparing to export the alpacas

$\begin{array}{lll}2.2 & \text { Exploring possible routes (1852) } & 31\end{array}$

2.3 Preliminary visit to Australia (1853) 36

2.4 An early crossing of the Cordillera (1853) 38

2.5 Reunited with the flock (1853-1854) 42

2.6 Snowstorms and ice (1854-1855) 43

2.7 Further problems and escapes (1855) 46

$2.8 \quad$ Argentina at last but no peace (1855-1856) 50

$\begin{array}{lll}2.9 & \text { At Laguna Blanca (1857-1858) } & 61\end{array}$

3. With the Alpacas to New South Wales 69

3.1 Crossing the Andes to the Chilean coast (1858) 69

3.2 The Australian debacle (1858-1863) 75

3.3 Digression on the early recognition of the fever-bark
tree 
4. Back to Peru-the Miraculous Seeds

4.1 The years of frustration and the return to Tacna (1864-1865)

4.2 Manuel and the seeds (1865)

4.3 The journey of the seeds to their destiny (1865)

4.4 Pedro's murder (1866)

4.5 The last two years in Peru (1867-1868)

4.6 Journeying once more from Tacna to Argentina (1869)

5. A General Trader Again

$\begin{array}{lll}5.1 & \text { Settling in Cachi (1869-1870) } & 135\end{array}$

5.2 Manuel's death (1871) 136

$\begin{array}{lll}5.3 & \text { The silent years as a trader }(1872-1875) & 137\end{array}$

5.4 The correspondence with J. E. Howard (1875-1883) 139

5.5 A digression on the exploitation of Ledger's seeds 153

6. After South America, the Last Years in Australia 166

6.1 The last period in Tucuman (1877-1883) 166

$\begin{array}{ll}6.2 & \text { London revisited (1883) } \\ 6.344\end{array}$

6.3 Back in New South Wales at Goulburn (1884-1890) 175

6.4 Tragedy strikes: Charlotte's death and the financial disaster (1891)

6.5 The fight to survive $(1892-1894) \quad 179$

$\begin{array}{ll}6.6 & \text { The Dutch pension }(1895-1896) \\ 6.71\end{array}$

$\begin{array}{lll}6.7 & \text { The final years }(1897-1905) & 187\end{array}$

$\begin{array}{ll}\text { 7. Two Epilogues } & 191\end{array}$

$\begin{array}{ll}\text { 7.1 Who was Charles Ledger? } & 191\end{array}$

$\begin{array}{lll}7.2 & \text { The more recent fate of ledgeriana } & 196\end{array}$

$\begin{array}{ll}\text { 8. Bibliography } & 199\end{array}$

A General articles and letters on Charles Ledger's life 199

B History of early cinchona explorations, bark and quinine 199

C The alpacas $\quad 200$

D Cinchona plantations and quinine 203

E Charles Ledger's last years (1895-1905); obituaries 206

F Official documents, private letters and poems 207

$\begin{array}{ll}\text { Indexes } & 209\end{array}$

$\begin{array}{ll}\text { Names } & 209\end{array}$

$\begin{array}{ll}\text { Places } & 212\end{array}$

Associations, Commissions, Governments, Magazines, Institutions and Vessels

$\begin{array}{ll}\text { Political, Social and Economic Events } & 217\end{array}$ 
Contents vii

Alpacas, Guanacos, Llamas and Vicuñas $\quad 218$

Cinchonas, Bark, Alkaloids and Malaria 219

Miscellaneous South American Products $\quad 221$

Local terms $\quad 222$

Tentative Ledger Family Tree and Distribution of its Members in England, Peru and Australia (facing page 222) 


\section{The figures}

Fig. I Coat of arms of Peru, showing alpaca, cinchona and cornucopia

Fig. 2 The old tombstone $x$

Fig. 3 The new, added tombstone xii

Fig. 4 Aunt Caroline-Sophia (Family Archives, Sydney) 3

Fig. $\quad 5$ Charles and Candelaria Ledger (Family Archives, Lima) 8

Fig. 6 Arthur Ledger (Family Archives, Lima) 9

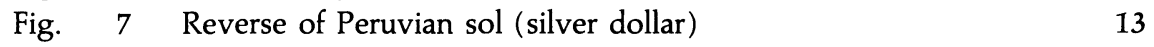

Fig. 8 Santiago Savage (Mitchell Library Archives (MLA), Sydney)

Fig. 9 The alpaca's annoyance (MLA, Sydney) 65

Fig. 10 Vignettes (MLA, Sydney) 66

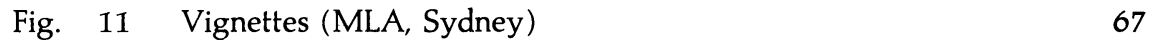

Fig. 12 Order for advance exploration (MLA, Sydney) 70

Fig. 13 Two of Ledger's medals (MLA, Sydney) 86

$\begin{array}{lll}\text { Fig. } 14 & \text { Eastern Andean slopes where cinchonas grow } & 113\end{array}$

Fig. 15 Manuel Incra Mamani (Archives of the Pharmaceutical Society of GB, London)

Fig. 16 Eminent quinologists (Archives of the Kina-Bureau, Maarssen)

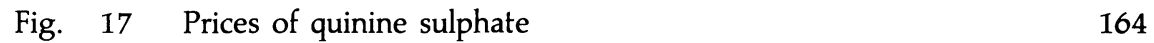

Fig. 18 Charles Ledger around 1880 (Family Archives, Lima) 171

Fig. 19 Charles Ledger in 1896 (Family Archives, Lima) 188 


\section{The colour plates and map of the regions of South America travelled by Ledger}

\begin{tabular}{|c|c|c|}
\hline Plate & 1 & Don Vicente and Ledger \\
\hline Plate & 2 & The outraged Don Vicente \\
\hline Plate & 3 & The burial of Pedro Ynora \\
\hline Plate & 4 & An electoral meeting \\
\hline Plate & 5 & At Patos, on the way to Laguna Blanca \\
\hline Plate & 6 & $\begin{array}{l}\text { Corrida de las Vicunas-the hunters getting comfortable } \\
\text { for the night }\end{array}$ \\
\hline Plate & 7 & $\begin{array}{l}\text { Corrida de las Vicuñas-early morning toast before } \\
\text { starting }\end{array}$ \\
\hline Plate & 8 & Corrida de las Vicuñas - the kill \\
\hline Plate & 9 & Arrival at Laguna Blanca \\
\hline Plate & 10 & Laguna Blanca-the 'parlour' \\
\hline Plate & 11 & The 'hatter' visits Laguna Blanca \\
\hline Plate & 12 & On the road to Santa Maria \\
\hline Plate & 13 & Crossing a river to Santa Maria before the storm... \\
\hline Plate & 14 & $\ldots$ and after the storm \\
\hline Plate & 15 & Landscape of the road to the valley \\
\hline Plate & 16 & Landscape of the valley \\
\hline Plate & 17 & Laguna Blanca-the llama nurses of the young vicuñas \\
\hline Plate & 18 & Laguna Blanca-skating lesson \\
\hline Plate & 19 & $\begin{array}{l}\text { One of the series of passes up towards El Paso } \\
\text { de San Francisco }\end{array}$ \\
\hline Plate & 20 & Another pass \\
\hline Plate & 21 & Early departure for El Paso de San Francisco \\
\hline Plate & 22 & Sleeping on ice at night next to llamas \\
\hline Plate & 23 & Negotiating El Paso de San Francisco \\
\hline Plate & 24 & Collecting the animals dispersed in the snowstorm \\
\hline Plate & 25 & Dispersed animals being reassembled \\
\hline Plate & 26 & Starting the descent \\
\hline Plate & 27 & A halt during the descent \\
\hline Plate & 28 & $\begin{array}{l}\text { Benito Colque and his family carrying water to the } \\
\text { animals }\end{array}$ \\
\hline Plate & 29 & Map of the regions of South America travelled by Ledge \\
\hline
\end{tabular}




\section{Preface}

A $t$ the very end of a long period of work in Australia (1979-81), I came across a fascinating article in the Illustrated London News on the extremely adventurous life of Charles Ledger of whom, up to that moment, I had only known that his name had been given to a species of the cinchona tree. In the article I learned of his extraordinary endeavours and adventures, and also that the end of his long life he had been buried in a pauper's grave at Rookwood Cemetery, near Sydney. Being a malariologist, I was particularly prompted to find his tomb and pay tribute to the memory of this remarkable man.

This was not easy. The Rookwood Methodist Cemetery in Sydney is a huge burial ground. It is subdivided into a number of sections according to the various religions of the world: from Methodists and other protestant denominations and Anglicans, to Catholics, and then Hindus, Muslims, Buddhists and probably also agnostics put together into an independent section.

It is in the last that Charles Ledger is buried, as I found after a long perusal of the cemetery registers. The tomb, however, was not a pauper's grave. It was partly overgrown by vegetation, and in a state of partial disrepair. The tomb's serial number could hardly be read, but the grave was large, with an edge of stone all around it, and the tombstone was high and its limestone neatly inscribed in carved letters.

The names carved were those of Emma Garratt, who had died on 28 November 1899, and of Frederick Kingston Olliver, who had died on 31 March 1907, respectively brother and sister of Ledger's second wife.

No mention was made of Charles Ledger, who had died on 19 May 1905 and had been buried there six years after Emma Garratt and two years before Frederick K. Olliver (Fig. 2). Before leaving I collected a few wild flowers and laid them on the grave. From that moment, I started delving into the scattered records of Ledger's life, and the more I found the more I wanted to know about him. I became thoroughly fascinated by what he had done and endured, and I realised what an extraordinary man he had been and how little he got in return for the enormous benefits he gave-or attempted to give-to mankind.

Charles Ledger deserves more-and a tomb that bears his name would seem the very least part of the recognition which is undoubtedly due to him. It is gratifying 
Preface xi

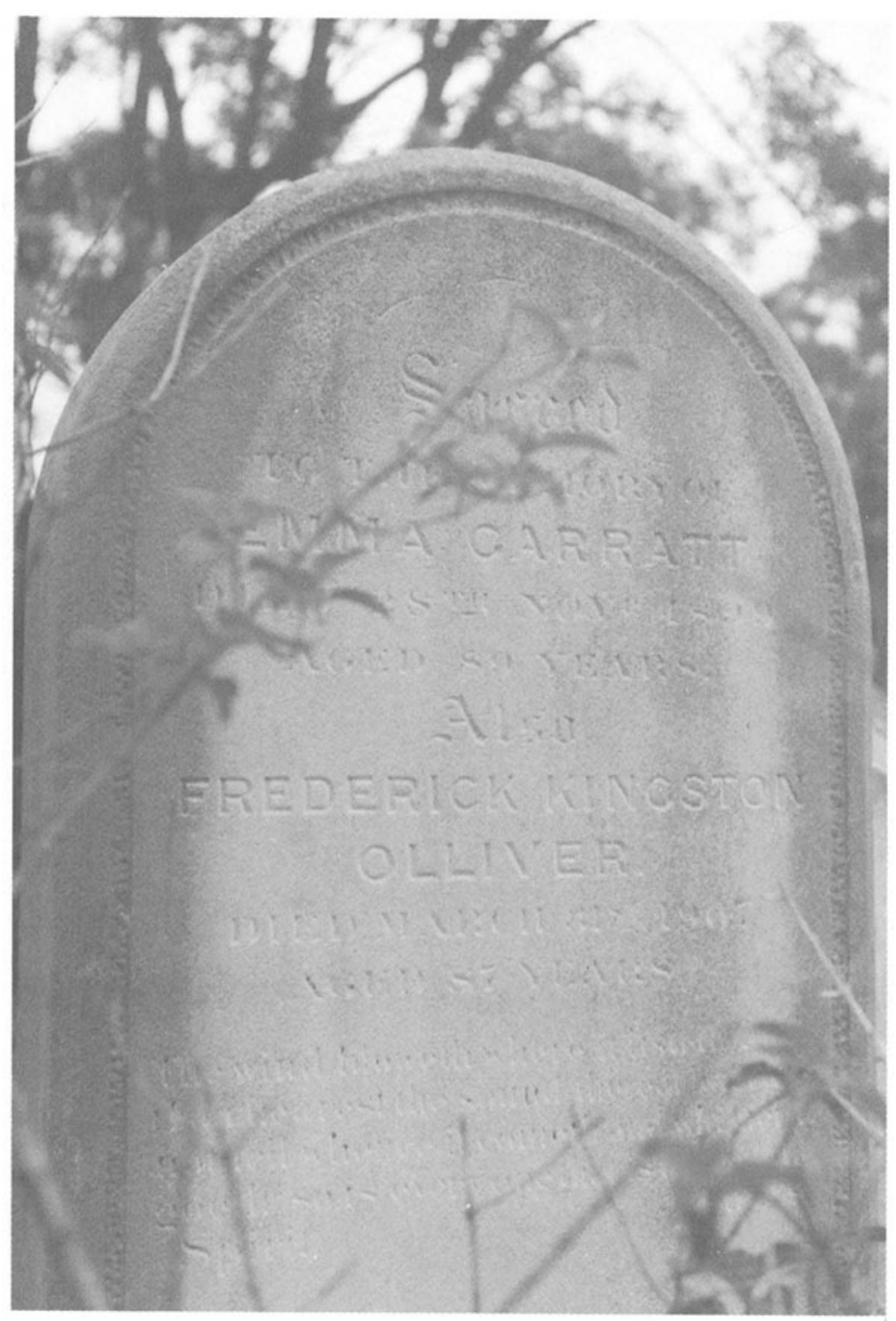

Fig. 2 The old tombstone 
xii Preface

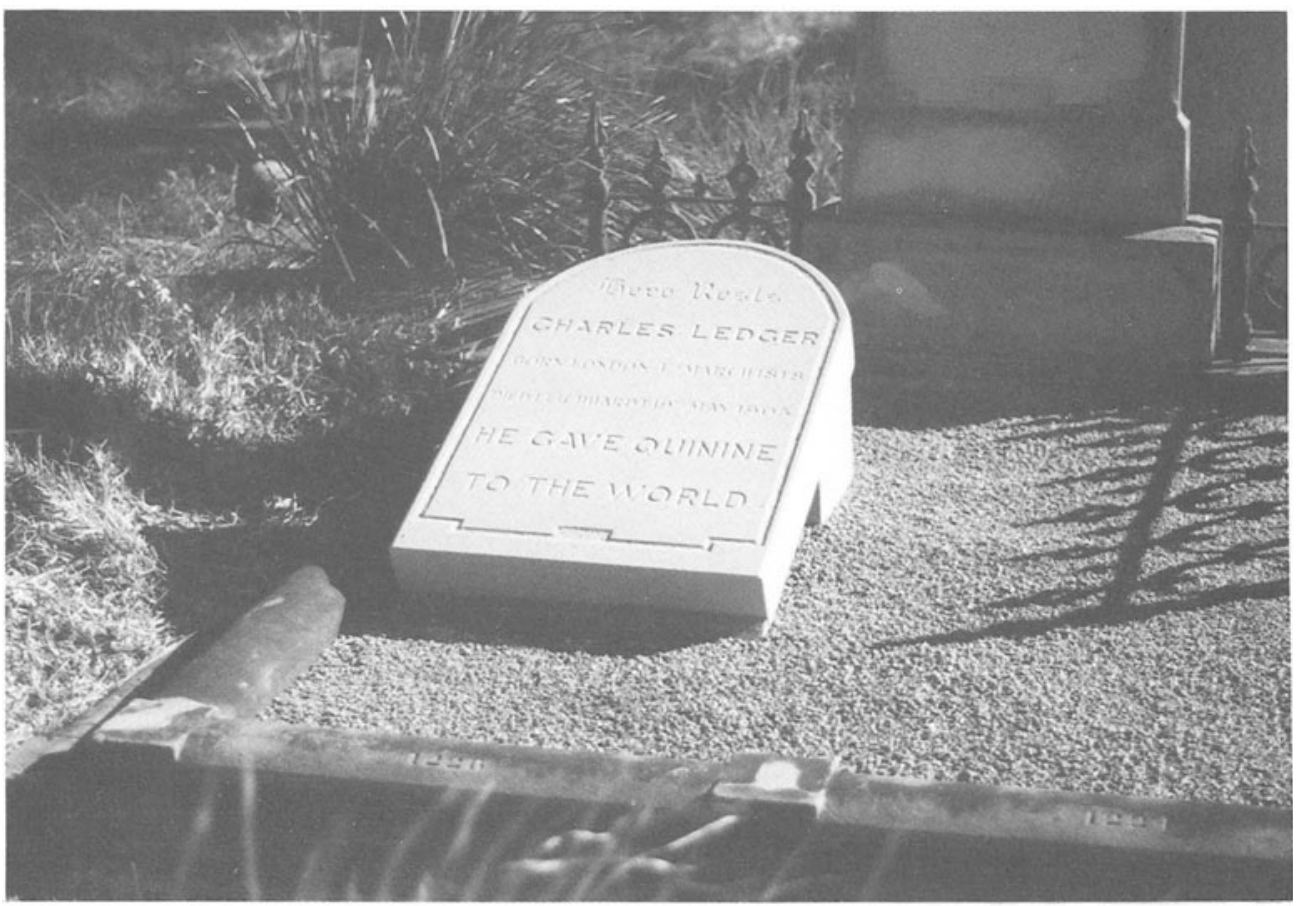

Fig. 3 The new, added tombstone

that a tombstone with Charles Ledger's name has now been added to the tomb, in September 1986, thanks to a donation from the Dutch quinine manufacturer ACF Chemiefarma NV (Fig. 3).

Cortona, Italy, 1987

G. Gramiccia 


\section{Acknowledgements}

The realisation of this book has been possible thanks to the invaluable help and patience of the many friends who, in England, Italy, USA, Australia, Peru, the Netherlands and Switzerland, became 'hooked' with me on the story of Charles Ledger.

In particular I wish to thank:

Rosemary Bell-Madsen, Geneva, who first drew my attention to the story of Charles Ledger.

John Koster, Queensland, Australia, who urged me to write the book.

Professor R. H. Black, NSW, Australia, who helped me in many ways; together, we discovered the tomb of Charles Ledger.

Mr John Packer, for his search for references in Sydney Libraries.

Mr Brian Turner for giving me copies of his slides of the watercolours of Ledger's diary on the alpacas.

Ms Margaret Wentworth for bibliographical assistance and for establishing contacts with Ledger's relatives in Australia.

Mrs Robbie Ledger, Mrs Merl Ledger and in particular Miss Catherine Matters, for their fruitful search of family and public archives in NSW and Queensland.

Mr R. F. Holden, Sydney, for his sharp analysis of the bank crisis in 1891.

Mr K. W. Hodgson, Sydney, for his valuable recollections of the alpaca sale.

The Mitchell Library, Sydney, and especially Miss Shirley Humphries, for the use of their archives and for permission to photograph some of the watercolours and documents and to reproduce them.

The NSW State Archives for permission to use extracts of documents in their files.

Mr N. Wietmayer, The Smithsonian Institute, Washington, DC, for providing information and references. 
Mr E. J. Lamb, Cuzco, Peru, for his help in finding and contacting Ledger's descendants in Peru.

Mrs A. M. del Rio de Aguilar, Lima, Peru, for providing photos, documents and information on the Ledger family.

Dr L. Cavagnaro Orellana, Chief of the Departmental Archives, Tacna, Peru, for his search of acts concerning $C$. Ledger.

The Wellcome Tropical Institute, London, and particularly Mr E. Freeman, Librarian, and Mr R. Price, Deputy Librarian, for their assistance in obtaining permission to consult relevant archives in London.

Prof. L. J. Bruce-Chwatt for his usual many-sided assistance in matters like this.

The Royal Botanic Gardens, Kew, and especially Miss L. E. Thomson, Assistant Librarian, for permission to scrutinise their archives and for assistance in photocopying the relevant material.

The Royal Pharmaceutical Society of Great Britain, London, and especially Miss M. F. Mackenzie, Assistant Librarian, for assistance in consulting their archives and permission to use the relevant material.

Mrs Jane Burlinson, London, for the long and laborious work of editing my English and for making useful suggestions.

Mrs Diana Macalpine, Chelsea Physic Garden, London, for some bibliographical and genealogical research on Charles Ledger's family in London.

Dr Ir E.H.D. Smit, and ACF Chemiefarma NV, Maarssen, the Netherlands, for the invaluable support given to the publication of the book.

Dr J. H. H. Heuschen, Maarssen, the Netherlands, for making available for perusal the archives of the former Kina-Bureau and assisting in the selection of relevant material.

My wife Muriel for typing, retyping, 'WORDSTARing' and correcting the various phases of the text with incredible patience towards the text and myself. 